\title{
Discover Our Model: The Critical Need for School-Based Immigration Legal Services
}

\author{
Prerna Lal* and Mindy Phillips**
}

This piece seeks to chronicle the development of school-based immigration legal services at the East Bay Community Law Center, evaluate the successes and challenges of our model, and provide guidance to other organizations across the country that may wish to emulate the model.

\section{INTRODUCTION}

In a political and social context where the Trump Administration has vilified immigrants ${ }^{1}$ and anti-immigrant sentiment is heightened, meeting the need for accessible, safe, and reliable legal support is more important than ever. East Bay Community Law Center (EBCLC) attorneys visit college and primaryschool campuses weekly to provide legal services to students and their families. Through UC Berkeley's Undocumented Students Program and a Medical-Legal

DOI:https://doi.org/10.15779/Z385X25C70

Copyright (C) 2018 California Law Review, Inc. California Law Review, Inc. (CLR) is a California nonprofit corporation. CLR and the authors are solely responsible for the content of their publications.

* Prerna Lal is a Staff Attorney and Clinical Supervisor at the East Bay Community Law Center. They provide legal services for the UC Berkeley Undocumented Student Program. They graduated from the George Washington University Law School in 2013.

** Mindy Phillips is a Staff Attorney and Clinical Supervisor at the East Bay Community Law Center. She provides legal services at school-based health centers in the Oakland Unified School District. She graduated from the University of California, Berkeley, School of Law in 2015.

1. See, e.g., Michelle Ye Hee Lee, Donald Trump's False Comments Connecting Mexican Immigrants and Crime, WASH. POST (July 8, 2015), https://www.washingtonpost.com/news/factchecker/wp/2015/07/08/donald-trumps-false-comments-connecting-mexican-immigrants-and-crime [https://perma.cc/T54J-U3CT]; Katie Zezima, Trump on Immigration: There are 'Bad Hombres' in the United States, WASH. POST (Aug. 30, 2017), https://www.washingtonpost.com/news/postpolitics/wp/2016/10/19/trump-on-immigration-there-are-bad-hombres-in-the-united-states [https://perma.cc/URS2-3889]. 
Partnership ${ }^{2}$ with La Clinica de la Raza's ${ }^{3}$ school-based health centers ${ }^{4}$ in the Oakland Unified School District, ${ }^{5}$ EBCLC's immigration attorneys have fashioned a creative service model that meets students and their families where they are-literally and figuratively-often on the school campus itself or the health center where they receive primary care. In this piece, we offer a summary of our on-site model in hopes of inspiring other legal-services organizations to replicate it. First, we discuss how obtaining legal status is critical to the economic, psychological, and academic well-being of undocumented immigrants. Next, we share the history of our two school-based models, describe how attorneys serve undocumented students on-site, and discuss the advantages of this school-based approach. Finally, we share best practices for replicating this model for other school campuses.

\section{WHY LEGAL STATUS MATTERS}

At La Clinica's school-based health centers (SBHC) in East Oakland, a Medical-Legal Partnership (MLP), a nurse practitioner met with fourteen-yearold "Angela" for her annual check-up. The nurse learned, over the course of their conversation, that Angela's mother Jacquelin might be interested in talking to an immigration lawyer. She faxed a referral to EBCLC's office, and the next week, Jaquelin met the immigration attorney at the SBHC on her daughter's school campus for a free legal consultation. Jaquelin is a thirty-five-year-old mother of three United States citizen children. Jaquelin is a single parent, and two of her children have special-education needs. She has lived in the United States for more than twenty years and had never spoken to an immigration lawyer before her appointment through the MLP. With EBCLC's legal assistance, Jaquelin obtained Deferred Action for Childhood Arrivals (DACA) in 2017 and, for now, she can work legally to support herself and her children. Obtaining DACA also qualified her for full-scope Medi-Cal health insurance. Since President Trump terminated the DACA program in September 2017, Jaquelin has suffered from anxiety about her children's uncertain future if she cannot continue to work legally, and she fears she will be separated from her three young children.

2. A Medical-Legal Partnership is a healthcare and legal-services delivery model that aims to improve the health and well-being of vulnerable individuals by integrating legal assistance into the medical setting.

3. LA CLINICA, http://www.laclinica.org [https://perma.cc/6JTJ-HJRX].

4. La Clinica's school-based health centers provide primary care, behavioral health services, health education, dentistry services, and much more. For example, see Havenscourt Health Center, LA CLINICA, http://www.laclinica.org/Havenscourt [https://perma.cc/X9UK-U4G3] (listing services offered by the organization).

5. School-Based Health Centers, OAKLAND UNIFIED SCH. DisT., https://www.ousd.org/Domain/140 [https://perma.cc/5DW4-ZXKP].

6. We have changed all clients' names in this piece to protect their confidentiality. 
As Jaquelin's story demonstrates, providing immigration legal services through schools and health centers can significantly enhance the quality of life of both students and families. Lawful immigration status and work authorization impact the economic security, psychological and physical well-being, and academic outcomes of previously undocumented immigrants. ${ }^{7}$ With respect to economic security, a Department of Labor-commissioned survey following the 1986 immigration legalization act shows that immigrants made significant wage gains following legalization. ${ }^{8}$ A 2016 survey of DACA ${ }^{9}$ recipients reported that 95 percent were currently working or in school, 48 percent obtained jobs with better working conditions, and 63 percent obtained jobs with better pay than before they had DACA. ${ }^{10}$ While research is ongoing, a survey of 3,573 undocumented households found that even temporary legalization programs such as DACA reduced the likelihood of household poverty by 38 percent. ${ }^{11}$ The promising economic outcomes that stem from obtaining legal status accompanied by work authorization lend support to making legal services easily accessible through this type of school-based model.

Social determinants of health, ${ }^{12}$ including income and health insurance, housing and utilities, education and employment, personal and family stability, and legal status, account for 60 percent of a person's health. ${ }^{13}$ Looking at legal status and its intergenerational effects on mental health, the Stanford Immigration Policy Lab published a study in September 2017 that compared the

7. See Mary Duan, DACA eligibility for mothers improves children's mental health, STANFORD MED. NEWS CTR. (Sept. 15, 2017), https://med.stanford.edu/news/all-news/2017/09/dacaeligibility-for-mothers-improves-childrens-mental-health.html [https://perma.cc/6LMK-2D8D] (quoting author of research on DACA recipients as saying "[ $[$ there are a lot of beliefs about policies, but not a lot of evidence on how policies impact the undocumented and the communities in which they live").

8. Legalized Population Survey, Match 1989-1992 File, Population StUd. CTR., https://www.psc.isr.umich.edu/dis/data/catalog/detail/796 [https://perma.cc/3276-FZ2L].

9. On September 5, 2017, Attorney General Jeff Sessions announced President Trump's rescission of DACA - a program created by President Obama in 2012 that provides renewable two-year work permits and protection from deportation for undocumented young people who came to the United States before the age of sixteen and who satisfy additional requirements. At the time of this piece's writing, it is unclear whether the program will continue or whether DACA recipients' work permits will begin to expire after March 5, 2018. Consideration of Deferred Action for Childhood Arrivals (DACA), U.S. CITIZENSHIP \& IMMIGR. SERVS., https://www.uscis.gov/archive/consideration-deferred-actionchildhood-arrivals-daca [https://perma.cc/XNG7-4S5J].

10. New Report Shows the Success of Four Years of DACA, UNITED WE DREAM (Oct. 18, 2016), https://unitedwedream.org/new-report-shows-the-success-of-four-years-of-daca [https://perma.cc/XW7S-3T5U].

11. See Catalina Amuedo-Dorantes \& Francisca Antman, Can Authorization Reduce Poverty Among Undocumented Immigrants? Evidence from the Deferred Action for Childhood Arrivals $\begin{array}{lllll}\text { Program, } & 147 & \text { ECON. } & \text { LETTERS } & 1,\end{array}$ http://www.sciencedirect.com/science/article/pii/S0165176516302968 [https://perma.cc/JV52-PHYR].

12. Medical-Legal Partnerships aim to address social determinants of health which are the social, economic, environmental, and legal factors that impact health outcomes and health inequities.

13. Elizabeth H. Bradley \& Lauren A. Taylor, The american Health Care PARADOX (2015). 
mental health of US-born children of mothers eligible for DACA and undocumented mothers ineligible for DACA. Co-author Jens Hainmueller described the findings: "We found that before DACA was implemented, the rates of mental health diagnosis were exactly the same; but in the post-DACA period, mothers started to benefit from protection and the rates of adjustment and anxiety disorders dropped by half." 14 This significant improvement in mental health post-DACA suggests why, without access to legal services and legal status, many immigrant high school and college students report stress, anxiety, depression, and other health issues - all known to profoundly impact health outcomes. ${ }^{15}$ In a politically hostile climate, the UC Berkeley Undocumented Students Program (USP) reports that demand for mental-health services doubled over the last year. ${ }^{16}$ This is mainly because the fear of family separation and the financial insecurity create significant emotional distress for students. ${ }^{17}$ Not surprisingly, a recent survey with a cross-section of 487 Latino immigrant students across California found that they reported better health after a transition to a lawful status. $^{18}$

It is also worth noting the intersection of legal status and health insurance. While the associated benefits of DACA vary by state, DACA recipients in California are eligible for full-scope Medi-Cal, California's Medicaid healthinsurance program for low-income residents. ${ }^{19}$ The UC Berkeley Labor Center estimated in 2013 that 60 percent of Californians eligible for DACA qualified as low-income under Medi-Cal eligibility standards and lacked private insurance. ${ }^{20}$ As DACA recipients start to lose their protected status with the program's termination, they will once again lose access to healthcare. Through EBCLC's

14. Duan, supra note 7.

15. See Ruben Castaneda, Trump Stokes Anxiety Among U.S. Citizen Kids of Undocumented Parents, U.S. NEWS \& WORLD REP. (Sept. 28, 2017, 11:00 AM), https:/health.usnews.com/wellness/mind/articles/2017-09-28/trump-stokes-anxiety-among-us-citizenkids-of-undocumented-parents; INT'L HuMAN RightS L. CLINIC, U.C. BERKELEY, SCH. OF L., DREAMERS AT CAL 14, 17-18 (2015), https://www.law.berkeley.edu/wpcontent/uploads/2015/04/DREAMersReport_Single_20150506134631_717508.pdf [https://perma.cc/RE5Q-HZG3].

16. Nicole Freeling, Undocumented Programs Offer Students a Lifeline in an Uncertain Era, U. OF CAL.: NEWS (Sept. 20, 2017), https://www.universityofcalifornia.edu/news/undocumentedprograms-offer-students-lifeline-uncertain-era [https://perma.cc/DK8L-ZK6Y].

17. Id.

18. See Caitlin Patler \& Whitney Laster Pirtle, From Undocumented to Lawfully Present: Do Changes to Legal Status Impact Psychological Wellbeing Among Latino Immigrant Young Adults?, SOC. SCI. \& MED. (forthcoming) (manuscript at 6).

19. Claire D. Brindis, et al., Realizing the Dream for Californians Eligible for Deferred Action for Childhood Arrivals (DACA): Demographics and Health Coverage (2014), $\mathrm{http}$ ://laborcenter.berkeley.edu/realizing-the-dream-for-californians-eligible-for-deferred-action-forchildhood-arrivals-daca-demographics-and-health-coverage [https://perma.cc/X5EA-MT7K].

20. Laurel Lucia et al., Health Insurance and Demographics of California Immigrants Eligible for Deferred Action, in CAL. POLICY Options 2016, at 93 (Daniel J.B. Mitchell ed., 2016), http://laborcenter.berkeley.edu/pdf/2016/Health-Insurance-and-Demographics-of-CaliforniansEligible-for-Deferred-Action.pdf [https://perma.cc/MK5J-YSC6]. 
partnership with the SBHC, more than ninety individuals ${ }^{21}$ are newly eligible for full-scope Medi-Cal, and many of them are also eligible for other public benefits. ${ }^{22}$ These findings and factors regarding legal status and health outcomes reinforce the need for and benefits of school-based legal services.

Finally, legal status impacts educational outcomes. A recent DACA survey reports that 70 percent of recipients currently in school are pursuing a bachelor's degree or higher. ${ }^{23}$ Of the recipients currently in school, 92 percent "said that because of DACA, 'I pursued educational opportunities that I previously could not." "24 Students perform better academically when they are in a safe and supportive school environment and are not subject to the stress caused by their own or their parents' undocumented status. ${ }^{25}$ Internal data from USP suggests that undocumented students at Berkeley have the same student-retention rates as their US citizen peers, which is commendable given the additional financial, psychological, and legal barriers they face. Moreover, the average cumulative grade point average for USP participants in Spring 2015 (369 undergraduates) was 3.11 compared to 3.29 for all undergraduates. ${ }^{26}$ One would expect that as legal barriers for undocumented students pursuing higher education dissipate, along with the related emotional and financial stress they endure, their academic performance will improve.

\section{BRIEF HISTORY OF USP LEGAL SERVICES}

Given the central premise that legal status is critical to life outcomes, in 2010 staff and students from the UC Berkeley Immigrant Student Issues Coalition forwarded several recommendations to then-Chancellor Robert Birgeneau regarding the needs of undocumented students on the Berkeley campus. Chancellor Birgeneau established a task force to articulate the issues and needs facing undocumented students on campus and to make recommendations for how to serve this population. ${ }^{27}$ The resulting Standing Committee for Undocumented Members of the On-Campus Community worked

21. Ninety-three individuals as of Nov. 21,2017. Data on file with the authors.

22. For example, U-Visa applicants living in California are eligible to apply for full-scope MediCal, Cal Fresh food stamps, and CalWorks cash assistance after they file their application with USCIS.

23. Tom K. Wong et al., New Study of DACA Beneficiaries Shows Positive Economic and Educational Outcomes, CTR. FOR AM. PROGReSS (Oct. 18, 2016, 12:00 PM), https:/www.americanprogress.org/issues/immigration/news/2016/10/18/146290/new-study-of-dacabeneficiaries-shows-positive-economic-and-educational-outcomes [https://perma.cc/LW23-EZZT].

24. Id.

25. Castaneda, supra note 15; DREAMERS AT CAL, supra note 15, at 14, 17-18.

26. U.C. BERKELEY, Five-YEAR STRATEGIC Plan FOR CAL'S UNDOCUMENTED STUdENT PROGRAM (2016), http://undocu.berkeley.edu/wp-content/uploads/2016/03/USP_FinalStrategicPlan1.pdf [https://perma.cc/9FYE-LJ56].

27. U.C. Berkeley, Chancellor's TASK ForCE ON UndOCUMENTED MEMBERS OF THE On-CAmpus CMTy., Recommendations to Chancellor Birgenau (2011), http://diversity.berkeley.edu/sites/default/files/undocumented-students-task-force-2011recommendations.pdf [https://perma.cc/UZ6D-DQFA]. 
to implement the recommendations and support further research and advocacy with and for undocumented members of the community. The initial task force recommended creating a staff position to work specifically on improving undocumented students' transition and access to on-campus resources. The university appointed Meng So as the Undocumented Student Program Coordinator, thus establishing the Undocumented Student Program (USP). Initially housed within the UC Berkeley Educational Opportunity Program, the program is now a part of the larger cluster of Centers for Educational Equity and Excellence.

In 2012, the International Human Rights Clinic at UC Berkeley School of Law, led by Professor Alison Davenport, started to provide legal consultations and referrals to undocumented students on the "Cal" (UC Berkeley) campus, thereby establishing the first campus-based immigration legal services program directly serving undocumented students in the United States. ${ }^{28}$ Altogether, the clinic served over 250 UC Berkeley students in three years. ${ }^{29}$ Due to the growing needs and numbers of undocumented Berkeley students, Meng So, now Director of USP, sought to hire a full-time attorney. Moreover, on the eve of Professor Davenport's departure from Cal, USP sought a more comprehensive placement for the legal services component of the program.

One option was to join the newly formed UC Immigrant Legal Services Center, which would have posted a Fellow at UC Davis who would commute weekly to Berkeley to provide services to undocumented students. ${ }^{30}$ But USP determined that a full-time, on-site attorney would optimally serve students. Because EBCLC is the premier community-based clinic of Berkeley Law, with a holistic direct legal services program that had already represented several $\mathrm{Cal}$ students, EBCLC was the logical choice to host the legal-services component of the program. In the summer of 2015 a generous donation from an anonymous funder enabled EBCLC and USP to hire a full-time attorney to address the many needs of the undocumented student population on campus. The Memorandum of Understanding between EBCLC and USP also allocated an initial $\$ 100,000$ to pay for students' US Citizenship and Immigration Services (USCIS) application fees, including fees for legal permanent residency applications (i.e. green cards) and DACA work permits. ${ }^{31}$

Since its inception, the USP legal-services program has expanded to include a full-time paralegal and an undergraduate work-study student, both of whom the USP attorney supervises. The legal-services program has also expanded to assist the parents of undocumented and US citizen students and

28. DREAMERS AT CAL, supra note 15 , at 5 .

29. Id.

30. See generally UC Davis Sch. OF L., UC Immigrant Legal Servs. CtR., https://law.ucdavis.edu/ucimm [https://perma.cc/XL58-DDHX].

31. Memorandum of Understanding (confidential, on file with authors); Email from Meng So, Director, USP, to Martha Brown, Director of Administration, EBCLC (July 10, 2017) (on file with authors). 
international students on campus who would otherwise lose lawful status without legal intervention. USP continues to cover immigration application and litigation fees for students. As a pioneer in services for undocumented students, USP has received requests from over two hundred college campuses and universities nationally to share its model, and it now hosts a website to assist in this endeavor. ${ }^{32}$ Various universities, including Harvard, have started to model the legal-services component of their undocumented-student program based on the current USP-EBCLC collaboration. ${ }^{33}$

\section{BRIEF History OF SCHOOL-BASEd MediCAL-LEgal PARTNERShIP}

In 2010, EBCLC launched on-site legal clinics in several Oakland Unified School District (OUSD) middle schools. This was part of a national effort by The Atlantic Philanthropies to fund the implementation of the community school model in under-resourced middle schools. ${ }^{34}$ The community school model brings health, legal, and other support services directly to school campuses to address barriers to education. ${ }^{35}$ Initially, EBCLC's legal services and La Clinica's medical services were both located on school campuses, but there was no formal partnership between the two organizations. As medical providers noticed that patient access to legal help generated positive impacts on issues from eviction to disability benefits to immigration, they sought to formalize the collaboration as a MLP $^{36}$ embedded in La Clinica's school-based health centers. These health centers are located on-site or within just a few blocks of elementary, middle, and high school campuses. Twice a month, an EBCLC attorney held office hours at three of the health centers, primarily receiving client referrals from La Clinica and school staff. Medical and school personnel made around six hundred referrals to EBCLC's legal services from 2010-2014. In 2014, EBCLC also established a Memorandum of Understanding with OUSD, affirming the school district's support of the partnership. ${ }^{37}$

In the partnership's first four years, students and families who were referred to EBCLC identified immigration as their number one legal need; in response,

32. See Discover Our Model, U.C. Berkeley: Undocumented Student Program, https://discoverourmodel.berkeley.edu [https://perma.cc/NMK2-GG3S].

33. See Jamie D. Halper, Inside the Clinic Leading Harvard's Response to Trump, HARV. CRIMSON (Feb. 10, 2017), http://www.thecrimson.com/article/2017/2/10/immigration-refugee-clinicresponse [https://perma.cc/T896-UDRC].

34. See Wendy S. McClanahan \& Kelly Piccinino, Research for Action, Elev8 FINAL REPORT (2016), http://www.atlanticphilanthropies.org/app/uploads/2016/12/Elev8-finalreport.pdf [https://perma.cc/EA32-AUQJ] (final report about the Elev8 Full Service Community Schools).

35. Id.

36. See East Bay Medical-Legal Partnerships, NAT'L Ctr. FOR Med.-Legal P'ShIP, http://medical-legalpartnership.org/partners/east-bay-medical-legal-partnership [https://perma.cc/Q4WM-KFVA].

37. Memorandum of Understanding Between EBCLC and OUSD (2014) (confidential, on file with authors). 
in 2015, EBCLC incorporated an Equal Justice Works (EJW) fellow to focus solely on immigration issues within the partnership. ${ }^{38}$ The Equal Justice Works fellow (now an EBCLC staff attorney) holds two immigration clinics per month at four of the health centers that directly serve eight schools. During the two-year fellowship period from September 2015 to September 2017, EBCLC received over five hundred client referrals from medical and school staff for immigration services, in addition to direct contacts from students and families referred via word-of-mouth. ${ }^{39}$ More than 80 percent of individuals referred received a legal consultation and screening for immigration relief. The EBCLC staff attorney also provides on-site workshops for students and families on topics such as common forms of immigration relief, "Know Your Rights" information for interactions with local law enforcement and Immigration and Customs Enforcement (ICE), ${ }^{40}$ and college access for undocumented students. While school-based health centers ${ }^{41}$ and MLPs operate across the country as independent entities, EBCLC's is the first MLP located in a school-based health center with such an intensive and consistent level of on-site presence and integration.

\section{WHY SHOULD IMMIGRATION LAWYERS BE ON Site?}

\section{Access}

Traditionally, lawyers work in offices where clients go for appointments. Our model for serving immigrant clients involves lawyers going to the clients and even meeting them where they go to school or see their doctor. Immigrant clients, especially newer arrivals to the country, are less likely to know how and where to seek legal services, so the familiarity and convenience of school campuses and health centers matters to them. Indeed, before walking through our offices, most of our clients have never spoken to an attorney. Moreover, onsite placement is critical because immigrant clients often stumble upon our legal services while seeking academic counseling or medical services, only to find out that an attorney can assist their whole family with an immigration matter, which is often intertwined with their academic and health concerns. In OUSD, students travel an average of 2.1 miles to the school they attend, meaning that schoolbased legal services are easily accessible because of the proximity to students' homes. ${ }^{42}$ Similarly, most Berkeley students live within a one-mile radius of

38. See Meet the Oakland Lawyer Working with Immigrants in 2017, EMERSON COLLECTIVE (Mar. 2017), http://www.emersoncollective.com/articles/2017/2/28/from-lawyer-to-guiding-lightserving-immigrant-families-under-trump [https://perma.cc/7U6N-Y8UD].

39. Internal data for EBCLC's school-based MLP (on file with authors).

40. Know Your Rights, ACLU, https://www.aclu.org/know-your-rights?topics=270 [https://perma.cc/CQT5-QPMB]. DGG4].

41. See SCHOOL-BASED HeAlTH All., http://www.sbh4all.org [https://perma.cc/SW2M-

42. OAKLAND Unified SCH. Dist., FAST FACTS 2013-14 (2014), https://www.ousd.org/cms/lib07/CA01001176/Centricity/Domain/4/OUSDFastFacts2013-14.pdf [https://perma.cc/6L8K-D4AD]. 
campus and EBCLC. For parents who do not live in the Bay Area, USP has built pro-bono and low-bono private-firm partners, especially in Los Angeles where many students maintain their permanent residence. In this manner, USP often serves as a gateway to local legal support for the entire family.

That students and parents have easy, ready access to legal services through the USP and MLP reduces the barriers to obtaining legal assistance. Indeed, according to MLP program figures, about 75 percent of students and parents had never spoken to an attorney previously about their case. Of these students and parents, about 30 percent were actually eligible for some sort of immigration relief or status. USP data further illustrates that once students access our immigration legal services for the first time, they are made aware of and seek other legal services offered by EBCLC (e.g. eviction defense, appeals for publicbenefits denials), and also refer their family members and friends for help. ${ }^{43}$

\section{Safe Spaces and Trusted Relationships}

School-based legal services leverage the relationships between students and families with their schools and health centers. The people who students and families trust the most-teachers, principals, academic counselors, medical providers, and mental health therapists - help our clients overcome the fear associated with accessing legal services, particularly the fear of disclosing their undocumented status. ${ }^{44}$ In the SBHCs in Alameda County, where EBCLC serves the majority of its clients, 98 percent of patients report that it is easier to talk to SBHC providers than to other doctors or nurses. ${ }^{45}$ Speaking with a lawyer can be intimidating; it is not always obvious to immigrants how a lawyer might address a housing, public benefits, or school discipline issue. However, lawyers defend tenants against eviction, appeal wrongful denials of disability benefits, and enforce the rights of young people facing expulsion. With school-based legal services, students and parents are referred to MLP and USP legal services by the institutions or people that they most trust.

This trust-building is especially important because schools ${ }^{46}$ and health care centers are not always safe spaces for immigrants, who are predominantly

43. Internal EBCLC data from our client database (on file with authors).

44. It is important to acknowledge that schools and health centers are not always safe spaces for immigrants, so this model is most suited to places where schools and health centers have built trusting relationships with students and families.

45. See Key Findings About Our Health Centers, OAKLAND UNIFIED SCH. Dist.: SCHOOLBASED Health CTRS. (Nov. 14, 2016), https://www.ousd.org/Page/1082 [https://perma.cc/84BYLDLD].

46. The Southern Poverty Law Center has been monitoring incidents of hateful harassment since President Trump's election. Anti-immigrant harassment is the most prevalent category. Almost 40 percent of all harassment incidents have happened in school settings (K-12 and university/colleges). Update: Incidents of Hateful Harassment Since Election Day Now Number 701, S. POVERTY L. CTR.: HATEWATCH (Nov. 18, 2016), https:/www.splcenter.org/hatewatch/2016/11/18/update-incidentshateful-harassment-election-day-now-number-701 [https://perma.cc/CD8F-Q4QZ]. 
people of color. ${ }^{47}$ For example, the relationship between UC Berkeley and the undocumented student population continues to be contentious, given that students have had to advocate for access and equity on the campus and across the University of California system, often against a hostile university administration. ${ }^{48}$ A prime illustration of this tension is with respect to the current University of California President Janet Napolitano, who prior to assuming her post presided over the US Department of Homeland Security's record-breaking deportation orders, ${ }^{49}$ and her tenure as UC President has consequently been the source of much protest and advocacy. Furthermore, instead of receiving full institutional support, non-university donors such as the Haas Foundation continue to primarily support the USP in helping to meet the needs of the Berkeley student population . . Given this troubling history students are rightfully wary of university administration and any legal services associated with the university. Fortunately, USP has worked hard to address the on-campus climate and acclimate non-traditional students, and EBCLC's uniquely independent role and decades-long track record of community legal support helps placate student fears. In communicating with students at events on campus or during confidential legal consultations, USP staff members are very clear that the programs exists to serve directly impacted students and not the university.

\section{Age-Dependent Immigration Applications}

Because certain means to obtain legal immigrant status are age-dependent, early intervention for potentially eligible young people is necessary. For example, the U-Visa, which is available to victims of certain crimes who cooperate with law enforcement, allows the primary applicant to include children, siblings, and parents, but their eligibility depends on the age of the primary applicant and the age and marital status of the other family members. ${ }^{50}$

47. The top ten source countries are Mexico, India, China, Philippines, Vietnam, El Salvador, Cuba, Korea, Dominican Republic, and Guatemala. Jie Zong \& Jeanne Batalova, Frequently Requested Statistics on Immigrants and Immigration in the United States, MigRATION INFO. SOURCE (Feb. 26, 2015), http://www.migrationpolicy.org/article/frequently-requested-statistics-immigrants-andimmigration-united-states-0 [https://perma.cc/F2ZE-VPFE].

48. See Sahil Chinoy \& Adrianna Dinolfo, Students Protest UC President Janet Napolitano's Visit to Campus Thursday, DAILY CALIFORNIAN, http://www.dailycal.org/2014/02/13/students-protestuc-president-janet-napolitanos-visit-campus-thursday [https://perma.cc/7RYX-93WN]; Madeleine Pauker, Protestors Condemn Napolitano's Treatment of Undocumented Students, DAILY BRUIN (Apr. 13, 2016, 3:42 PM), http://dailybruin.com/2016/04/13/protestors-condemn-napolitanos-treatment-ofundocumented-students [https://perma.cc/X9CT-CRY5].

49. See Muzaffar Chishti, Sarah Pierce \& Jessica Bolter, The Obama Record on Deportations: Deporter in Chief or Not?, MigRATION INFO. SOuRCE (Jan. 26, 2017),

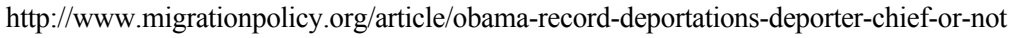

[https://perma.cc/78UE-DKTN] (noting on Table 1 that the Obama administration had issued a record number of formal orders of removal).

50. Victims of Criminal Activity: U Nonimmigrant Status, U.S. CITIZENSHIP \& IMMIGR. SERVS., https://www.uscis.gov/humanitarian/victims-human-trafficking-other-crimes/victims-criminalactivity-u-nonimmigrant-status/victims-criminal-activity-u-nonimmigrantstatus\#FilingforQualifyingFamilyMembers [https://perma.cc/L2CP-4BGP]. 
For instance, a nurse practitioner at one of the SBHCs referred Samuel to the MLP. Samuel is a sixteen-year-old high school student and DACA recipient who was physically assaulted while he was outside of a restaurant. He qualified for a U-Visa, and because he was under twenty-one years old, he was able to include his two undocumented parents in his application. ${ }^{51}$ Obtaining the U-Visa will eventually lead to legal permanent residency (a green card) and citizenship for all three of them. Because of their low income, filing the U-Visa also qualified them for full-scope Medi-Cal health insurance and public benefits such as food stamps. ${ }^{52}$ By helping Samuel and his family apply for the U-Visa through our MLP, we have ensured them greater economic and psychological security.

Likewise, Special Immigrant Juvenile Status (SIJS) confers permanent legal status upon children who have been abused, neglected, or abandoned by a parent, but applicants must take critical steps, such as seeking placement in a guardianship, before turning eighteen or twenty-one years old. ${ }^{53}$ Shortly after California raised the maximum age limit for guardianship from eighteen to twenty-one, the USP attorney encountered a SIJS-eligible student, Rodrigo, who sought legal help with an application to travel abroad. ${ }^{54}$ During a full consultation, he revealed that he had been orphaned at a young age in Mexico, placed into foster care, and that he had made his way to the United States to join his two older brothers. He was turning twenty-one in less than a month, rendering him ineligible for guardianship and hence, a green card through SIJS. Working with lawyers at EBCLC, he successfully obtained a state-court order finding him to be a child who was abandoned by his parents, just a couple of days before his twenty-first birthday, which made him eligible for immigration relief. Rodrigo now has lawful permanent resident status. Since 2015, EBCLC has successfully obtained SIJS predicate orders ${ }^{55}$ for ten UC Berkeley students who would have missed out on lawful permanent residence without timely intervention. ${ }^{56}$

In addition, common complications for immigration cases include prior contact with the police ${ }^{57}$ or immigration officials, and those complications are

51. U.S. Citizenship \& Immigr. Servs., Form I-918, Instructions for Petition for U Nonimmigrant Status and Supplement A, Petition for Qualifying Family Member of U-1 Recipient, at 2 (2017).

52. The additional benefits that U-Visa applicants qualify for vary by state.

53. Eligibility Status for SIJ, U.S. CitiZENSHIP \& IMMigr. Servs., https://www.uscis.gov/green-card/special-immigrant-juveniles/eligibility-sij-status/eligibility-status-sij [https://perma.cc/8Y8Y-48MX].

54. EBCLC News (E. Bay Cmty. L. Ctr., Berkeley, Cal.), Oct. 2016, http://ebclc.org/wpcontent/uploads/2016/12/October-2016-Issue-.pdf [https://perma.cc/9QU7-DGY7].

55. A predicate order issued by a state-court judge is the first step to obtaining SIJS status, which then leads to permanent residency. U.S. CITIZENSHIP \& IMMIGR. SERVS., supra note 53.

56. Legal Support, U.C. Berkeley: UndoCUMENTED STUdent Program, https://discoverourmodel.berkeley.edu [https://perma.cc/NMK2-GG3S].

57. Richard Perez-Pena, Contrary to President Trump's Claims, Immigrants Are Less Likely to Commit Crimes, N.Y. TIMES (Jan. 26, 2017), https://www.nytimes.com/2017/01/26/us/trump-illegalimmigrants-crime.html [https://perma.cc/WQ9D-UFRM]. Research from the Migration Policy Institute shows that the crime rate among undocumented immigrants is approximately $7.5 \%$. See Muzaffar 
less likely ${ }^{58}$ and often have less serious consequences for juvenile clients. ${ }^{59}$ Even seemingly minor criminal convictions, such as Driving Under the Influence ("DUI"), can affect an individual's ability to obtain immigration benefits and avoid deportation. ${ }^{60}$ This makes legal services for students that much more effective because they can submit applications for legal status and secure legal status before these complications arise. While even lawful permanent residents (i.e. green card holders) can be deported for criminal convictions, they generally have more avenues for relief and due process rights than undocumented immigrants with similar criminal histories. ${ }^{61}$ Persons who become US citizens through naturalization cannot be deported with extremely rare exceptions. ${ }^{62}$ Therefore, with early intervention through school-based legal services, the potential benefits of legal status are available to the student and family earlier, including increased stability, access to public benefits (including health insurance), work-authorization documents, and protection from deportation.

\section{Opportunity to Empower and Support Community-Driven Advocacy}

Social-justice lawyers can ally themselves with already-existing support or link students, families, and schools to grow the community's knowledge about social-justice issues and help them develop tools to advocate for themselves and one another. Through "Know Your Rights" workshops, dissemination of reliable information and resources, and participation in forming schools' policies and services, school-based lawyers assist with individual and collective empowerment.

Chishti \& Michelle Mittelstadt, Unauthorized Immigrants with Criminal Convictions: Who Might be a Priority for Removal?, MIGRATION POL'Y INST. (Nov. 2016), $\mathrm{http} / /$ www.migrationpolicy.org/news/unauthorized-immigrants-criminal-convictions-who-might-bepriority-removal [https://perma.cc/RH37-HLSQ].

58. Arrest data from 2008-2014 indicates that the arrest rate per 100,000 persons was 4,151 for persons age eighteen or older compared to 3,084 for persons under age eighteen. Estimated Arrests of All Persons in the United States, OfF. OF Juv. Just. \& DelinQ. Prevention, https://www.ojjdp.gov/ojstatbb/ezaucr/asp/ucr_display.asp [https://perma.cc/XU2P-46QK].

59. NAT'L Juv. Def. CTR., JuVEnile DEF'S Guide to IMMigRation ISSUES IN JuVENILE PROCEEDINGS (2017), http://njdc.info/wp-content/uploads/2017/12/Immigration-Brief_Final.pdf [https://perma.cc/BRW4-4EGL] ("Although a finding of delinquency is not a 'conviction' for purposes of immigration (and, thus, does not have the same dire consequences as a conviction), a juvenile arrest, charge, or adjudication may nonetheless trigger immigration consequences.").

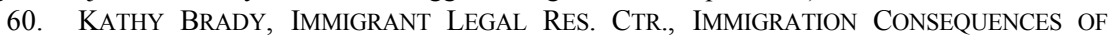

DRIVING UNDER THE INFLUENCE,
https://www.ilrc.org/sites/default/files/resources/dui_advisory_2final.pdf [https://perma.cc/46ZQLYU2].

61. See Immigration and Nationality Act $\S 240$ A, 8 U.S.C. $\S 1229 \mathrm{~b}$ (2012) (providing cancellation of removal for lawful permanent residents who have not committed an aggravated felony); see also Immigration and Nationality Act $\S 212(\mathrm{~h}), 8$ U.S.C. $§ 1182$ (2012) (providing a waiver for some lawful permanent residents who have committed aggravated felonies).

62. Allan Wernick, Naturalized U.S. Citizens Can't be Deported, Even for Crimes, N.Y. DAILY NEwS (May 20, 2016, 5:14 AM), http://www.nydailynews.com/naturalized-citizens-deported-crimesarticle-1.2643570 [https://perma.cc/E4JD-3LFX]. 
School campuses are built-in communities that enable students and their families to connect regularly with one another through personal, academic, and extracurricular activities. Students are often powerful forces for social justice and actively participate in their own and others' empowerment. For example, one of the high schools that the MLP serves uses student-peer advocates to share information about immigrants' rights and the legal services available through the SBHC on campus. At UC Berkeley, undergraduate student members of Rising Immigrant Scholars Through Education (RISE) were paramount in forming a critical mass of support for the creation of USP. They pressed for meetings with university administration, protested the University Office of the President, and occupied offices until their demands for educational equity and inclusion were met. ${ }^{63}$ Undocumented campus leaders have also been vocal in the mainstream media about how the university has failed to protect them. ${ }^{64}$ These advocacy efforts have been vital to the USP's expansion beyond just a student coordinator and to create wider institutional support for staff. Indeed, the students' advocacy has resulted in the university now contributing $\$ 50,700$ per year through student fees to cover the immigration attorney position. ${ }^{65}$ While this support is still wholly insufficient, ${ }^{66}$ that the university sanctions and partially funds this program at all is a testament to the students' successful advocacy in pushing the university to commit resources rather than just mere platitudes of support.

\section{Best PRACTICES}

For these reasons, colleges, primary schools, school-based health centers, and legal services organizations should partner to host immigration attorneys onsite. Partnering with a local legal-services organization or a law-school clinic draws upon the experience of organizations that already have collaborations and trust in the local community. On-site presence and relationship building are

63. See Ju Hong, The Case Against Napolitano's Nomination, DAILY CALIFORNIAN (July 16, 2013), http://www.dailycal.org/2013/07/16/against-the-napolitano-nomination [https://perma.cc/K9J4CZQ7]; J.D. Morris, In Meetings with UC Berkeley Students, Napolitano Hears Criticism and Policy Talk, DAILY CALIFORNIAN (Feb. 14, 2014), http://www.dailycal.org/2014/02/14/meetings-uc-berkeleystudents-napolitano-hears-criticism-policy-talk [https://perma.cc/8X6W-V8AT]; Josh Richman, Undocumented Students Disrupt Janet Napolitano's Speech at UC Summit, MERCURY NEWS (May 7, 2015, 5:43 AM), http://www.mercurynews.com/2015/05/07/undocumented-students-disrupt-janetnapolitanos-speech-at-uc-summit [https://perma.cc/7WUG-A9SR].

64. Juan Prieto, Even at Berkeley, I Face Threats as an Undocumented Student, N.Y. TIMES (Nov. 7, 2016), https://www.nytimes.com/2016/11/07/opinion/even-at-berkeley-i-face-threats-as-anundocumented-student.html [https://perma.cc/869B-H7H4].

65. Legal Support, U.C. Berkeley: Undocumented Student Program, https://discoverourmodel.berkeley.edu/program-components/programs-and-services/legal-support [https://perma.cc/RAG2-EQPK] ("Thus far, CACSSF has committed $\$ 50,700$ per year toward the attorney position, which is half of the total annual costs for salary and benefits.").

66. The allocation does not cover the salary for any of the legal staff members. Further, UC Berkeley still does not provide dedicated office spaces for the USP Director and USP legal team, an issue that continues to impede undocumented students' ability to access services on-site in a safe and confidential place. 
critical to ensure that immigrant populations, who have been historically denied access to legal services due to structural racism in the profession and wider community, receive the support that they sorely need.

Attorneys should also prepare to be highly mobile while on-site, with access to work laptops, cell phones, and on-site printing and servers so that initial consultations are efficient and productive for all parties. Meeting spaces on campus or at health clinics should be private enough to maintain attorney-client privilege and client confidentiality. Finally, placing a single attorney or fellow on-site is often shortsighted given the quantity and myriad need of low-income immigrant clients. Institutions that want to employ a similar model as ours should strive to provide one paralegal or assistant per attorney to maximize services to clients.

In the school-based health-center context, the immigration attorney should train health-care providers to spot legal issues and make referrals. EBCLC and La Clinica de la Raza have adapted common screening tools to fit this service model that are simple and accessible for patients and providers. In addition, the health-center staff and attorneys should conduct outreach with school staff, including administrators, family-resource centers, teachers, front-office staff, and support-services coordinators to generate referrals and organize workshops. Plugging into already established events, such as parent nights and school registration, is a great way to spread the word about the legal services available.

Critically, immigrant populations do not just need help with immigration matters, and so a holistic legal-services provider such as EBCLC can aid the community on more than just one legal matter. For example, UC Berkeley students have worked with EBCLC's Consumer Unit to resolve debt collection issues, the Community Economic Justice Unit to form worker-owned cooperatives for immigrant clients, the Health and Welfare Unit to complete name- and gender-change petitions for transgender clients, and the Clean Slate Unit to assist with traffic court and post-conviction relief matters. Berkeley students who come to us through the USP program also seek our assistance with tax and tuition residency matters on a regular basis. If the legal organization is not a "one-stop shop," it is critical to develop external relationships with other legal organizations that can assist the population with other matters besides immigration. While EBCLC focuses on providing on-site immigration services, the school-based model is adaptable to a host of legal needs that may be identified in other school and health communities.

Finally, paying for clients' immigration application fees also gives an incentive for people to come in for an initial consultation with an attorney and walk out with a comprehensive plan for their cases. For example, during a recent DACA renewal clinic, an applicant came in seeking fee assistance. After a full consultation, she learned that she was eligible for a U-Visa, so she not only had her application fees covered, but discovered that she had a pathway to citizenship. Moreover, paying for application fees also serves to invest in 
immigrant communities and ensures that those who are most vulnerable are not foregoing the long-term security and stability that legal status provides just because they cannot afford it.

\section{CONCLUSION}

School-based immigration legal services provide accessible and safe support to immigrant students and families. During a time when immigrant students and families are especially vulnerable to threats to their security and well-being, legal organizations, schools, and health centers need creative and collaborative tools to meet immigrants' needs and meet immigrants where they live, study, and work. The school-based on-site models EBCLC has developed effectively intervene at a strategic point in young people's lives and lead to work authorization and legal status that improve the economic, health, and academic outcomes of the students and families they serve. In these times, we are hopeful that school administrators seeking to assist their undocumented students, and local non-profits seeking to provide client-centered services, will replicate these models as a meaningful way to serve immigrant communities. 
